\title{
The Fama and French Five Factor Model: Evidence from an Emerging Market
}

\author{
Dr. Dima Waleed Hanna Alrabadi \\ Associate Professor \\ Department of Finance and Banking Sciences \\ Hanna Waleed Hanna Alrabadi \\ Lecturer \\ Department of Financial Economics \\ Faculty of Economics and Administrative Sciences \\ Yarmouk University, Jordan
}

\begin{abstract}
This study tests the five-factor model that has recently developed by Fama and French (2015). We use daily data of 84 companies listed in Amman Stock Exchange (ASE) over the period (2011-2015). The results indicate that there is a statistically significant effect of the common risk factors, excess market return (Rm-Rf), small minus big (SMB), high minus low (HML), robust minus weak (RMW) and conservative minus aggressive (CMA) on the cross section of daily returns in ASE. However, the Fama and French five factor model fails to perfectly explain the cross section of stock returns in ASE over the study period. These results could be mainly justified by the fact that ASE is an emerging market in which many unexpected factors apart from fundamentals may interfere in affecting stock returns.
\end{abstract}

Keywords: Fama and French, Five Factor Model, Profitability, Investment Growth, Amman Stock Exchange.

\section{Introduction}

What determines stock return is a dilemma that has been studied over years. There is no consensus till now on a certain model that perfectly describes the cross section of stock returns. The foundations of risk and return on individual stock level as well as portfolio level are established by Markowitz (1952) and Tobin (1958). Markowitz (1952) is the first to use mean-variance analysis to emphasize the risk factor of expected returns. He defines the expected return and variance of returns on a portfolio as the basic criteria for portfolio selection. In specific, Markowitz (1952) formulates the portfolio problem as a choice of the mean and variance of a portfolio of assets. Thus, he defines the efficient portfolio as the one that maximizes the expected return given a constant variance or minimizes variance given constant expected return. The first model that determines the rate of return on asset is introduced by Sharpe (1964) and Lintner (1965), it is the capital asset pricing model (CAPM). The CAPM is a single index model that relates the rate of return on a stock to its systematic risk measured by beta which in turn reflects the sensitivity of stock return to the changes in market return. It predicts a linear direct positive relationship between the asset's risk and return. The CAPM is considered as one of the fundamental contributions in finance, it has long been a guide for academics and practitioners of about the relationship between average returns and risk. However, the major weakness of the CAPM is its unrealistic assumptions, such as borrowing and lending unlimited amounts under the risk free rate of interest, no taxes or transaction costs, single investment period, efficient markets where information is available to all investors at no cost and at the same level. This model has evolved over time, and several forms of the CAPM are developed on relaxed and mode realistic assumptions. One of the leading and well-known derivations of the CAPM is the zero-beta CAPM of Black (1972). Black (1972) derives a new model of the CAPM by relaxing the assumption

* This Article Was Submitted in February 2017, and Accepted for Publishing in April 2017. 
of risk-free lending and borrowing. Black (1972) shows that the major results of the CAPM do not require the existence of a risk-free asset that has constant returns in every state of nature. Investors instead use a zero-beta portfolio; a portfolio of risky assets with zero covariance with the market portfolio. The zero-beta CAPM implies that beta is still the correct measure of systematic risk and the model still represents a linear positive direct relationship between risk and return. Merton (1973) derives a version of the CAPM that relaxes the single time period assumption, the inter-temporal CAPM (ICAPM). The ICAPM assumes a continuous time framework in which trading takes place continuously. In contrast to the standard CAPM, in the context of ICAPM investors are concerned not only with end of period wealth, but also with the opportunities of consumption and investment throughout the life of the stock. Thus, it is a linear factor model with wealth and state variable that forecast changes in the distribution of future returns or income. Breeden (1979) derives a Consumption based CAPM. It is a single beta asset pricing model in multi-good, continuous-time model with uncertain consumption goods prices and uncertain investment opportunities. In the Consumption CAPM, the equity premium is proportional to a single beta, which is the covariance with consumption (usually replaced with consumption growth per capita in empirical tests) rather than to the market portfolio. On the other hand, Cochrane (1991) develops an investment based CAPM. It considers the physical investment return of the firm. Thus, the model is obtained from a within-firm type of arbitrage: invest in the current period and then withdraw enough investment in the next period to keep the capital stock for future periods equal to what it would have been without the current period investment; the net payoff per unit extra investment in the current period is the investment return. Some researchers argue that the standard CAPM is a static model. They argue that the risk and return have a conditional relationship and consequently derive a conditional CAPM in which beta and the market risk premium are time varying (Jagannathan and Wang, 1996; Petkova and Zhang, 2005; Ang and Chen, 2007).

A growing number of studies find that the cross-sectional variations in average security returns cannot be explained by the market beta alone and show that fundamental variables such as size (Banz, 1981), ratio of book-to-market value (Rosenberg, Reid and Lanstein,1985; Chan, Hamao and Lakonishok, 1991), macroeconomic variables and the price to earnings ratio (Basu, 1983) account for a sizeable portion of the cross-sectional variations in expected returns. Ross (1976) introduces the Arbitrage Pricing Theory (APT) showing how to approximate equilibrium rate of returns using arbitrage portfolios in the framework of factor models. Factor models of asset prices postulate that rates of return can be expressed as linear functions of a small number of factors. The APT is a general theory of asset pricing that holds that the expected return of a financial asset can be modeled as a linear function of various macro-economic factors or theoretical market indices, where sensitivity to changes in each factor is represented by a factor-specific beta coefficient. Fama and French (1993) develop a multi index asset pricing model. In their model, the expected return on a portfolio in excess of the risk-free rate is explained by the sensitivity of its return to three factors: (i) the excess return on a broad market portfolio (RM- Rf); (ii) the difference between the return on a portfolio of small stocks and the return on a portfolio of large stocks (SMB, small minus big); and (iii) the difference between the return on a portfolio of high-book-tomarket stocks and the return on a portfolio of low-book-to-market stocks (HML, high minus low). Fama and French $(1992 ; 1993 ; 1996)$ assume that the financial markets are certainly efficient but the market factor does not explain all the risks on its own. They conclude that the three factor model does describe the assets returns. Carhart (1997) adds the momentum factor to the Fama and French three factor model to generate a four-factor model. The momentum factor is defined as the difference between the return on winners' portfolio (the stocks which performed best in the last 3-12 months) and the return on losers' portfolio (the stocks which performed worst in the last 3-12 months). Acharya and Pedersen (2005) present a liquidity adjusted capital asset pricing model. The security's required return in their model depends on its expected liquidity as well as on the covariances of its own return and liquidity with the market return and liquidity. The most recent multi index asset pricing model is the five factor model of Fama and French (2015). In this model, Fama and French add two additional pricing factors, the robust minus weak (RMW) which represents the difference between the returns 
on diversified portfolios of stocks with robust and weak profitability and the conservative minus aggressive (CMA) which represents the difference between the returns on diversified portfolios of low and high investment stocks. Fama and French (2015) argue that their five factor model explains the monthly stock returns of NYSE over the period 1963-2012. This study investigates the performance of the five factor model of Fama and French (2015) in an emerging stock market, Amman Stock Exchange. To the best of author's knowledge this is the first study worldwide that tests this recent model in an emerging stock exchange. The remaining of the study is organized as follows: Section 2 reviews the related literature, Section 3 describes data and methodology, Section 4 reports the results of analysis and Section 5 concludes.

\section{Literature Review}

A huge amount of research has focused on the performance of asset pricing models in different stock exchanges worldwide. The earliest evidence is introduced by Black et al. (1972) and Fama and MacBeth (1973) who find supporting results for the CAPM in NYSE. However, succeeding research contradicted the supportive results of the initial studies arguing that the standard CAPM is not able to explain the cross section of stock returns as a single index model, there are other important explanatory factors such as size and book to market ratio (Basu, 1977; Banz, 1981; Rosenberg et al., 1985; Fama and French, 1992).

Some other researchers test the conditional version of the CAPM. Pettengill et al. (1995) test the conditional relationship between beta and expected returns in USA over the period January 1926 through December 1990. Their findings support the existence of a highly significant conditional relationship between beta and returns for the full sample period and all sub-periods. Fletcher (1997) examines the conditional relationship between beta and return in UK stock returns and finds no evidence of a significant risk premium on beta when the unconditional relationship between beta and return is considered. When he splits the sample into periods according to whether the excess market return is positive or negative, he documents a significant relationship between beta and return. Fraser et al.(2004) study the same issue for the same market and find that the risk-return relationship is insignificant for up markets while it is significance for down markets. Theriou et al. (2010) tests the unconditional and conditional CAPM versions in Athens Stock Exchange. They find supporting evidence of the conditional model.

Many researchers examine the ability of the Fama and French three factor model in explaining the cross section of stock returns. Daniel and Titman (1996) test the Fama and French model on NYSE, AMEX and NASDAQ for the period 1963-1993. Their findings do not support Fama and French model. They conclude that there is no relationship between expected return and Fama and French common risk factors. However, Davis et al. (2000) test the model by extending Daniel and Titman's (1996) study from 1929 through 1997. They find a contradicting result with Daniel and Titman. Their study supports the validity of Fama and French model. Connor and Sehgal (2001) test the three-factor model in India. They use similar mimicking portfolio formation procedure to that of Fama and French (1993). Their results support the Fama-French three-factor model in Indian equity market. Faff (2001) tests the model in the Australian stock market by using shelf index and consistently his results support the Fama and French model. He finds that the estimated premia for the market and for the book-to-market factor are positive while the size risk premium is negative in the sample. Ajili (2003) tests the three factor model of Fama and French and the CAPM on the French Stock Market over the period 1976-2001. Her results show that the three factor model explains better the common variations in stock returns than the capital asset pricing model. Moreover, both the CAPM and the three factor model do a good job in explaining the cross section of stock returns. She tests the three factor model with a set of market portfolios and shows that all market portfolios capture the common variations in stock returns. However, only the value-weight market portfolio can explain the cross-section in the stock returns. Gokgoz (2007) test the CAPM and the three-factor model in the Turkish Stock Markets 
for the period of 2001-2006 and also finds that the three-factor model is applicable for the Turkish Stock Markets. Similar evidence is also shown by Chui and Wei (1998) in five Pacific-Basic emerging markets (Hong Kong, Malaysia, Taiwan, Korea and Thailand).

Some researchers test the performance of other multi-index models. Groenewold and Fraser (1997) compare the performance of the empirical version of APT and the CAPM using monthly Australian sectoral share-price indexes for 1980-1994. They conclude that the APT outperforms the CAPM in terms of its explanatory power. Tai (2003) investigates the effect of Fama and French three common risk factors and the momentum factor of (Carhat, 1997) on securities returns using monthly data from NYSE, AMEX and NASDAQ over the period from June 1953 to May 2000. He finds that all risk factors market return (RM-RF), size $(\mathrm{SMB})$, book-to-market (HML) and momentum (MOM) are significantly priced and reflected in stocks rate of return. The results show that these risk factors provide better explanation to the time-series variation in stocks return over the CAPM and the anomalies like size and book-to-market. His results also indicate that Momentum is not captured by the CAPM. L'Her et al. (2004) investigate the ability of the four factor model of (Carhart, 1997) to provide better explanation to the time- series variations in stock returns over the three factor model of Fama and French using monthly data from the Canadian stock market over the period from 1960 to 2001. They report strong evidence supporting the four factor model. Bello (2008) compares the CAPM, Fama and French three factor model and Carhart four factor model using equity mutual funds in USA over the period April 1986 to March 2006. He finds that the Fama and French model beat CAPM and that the four factor model provides a superior prediction of return over Fama and French model. Al-Rjoub et al. (2010) empirically investigate the cross-sectional behavior of stock returns in four emerging markets, namely, Egypt, Jordan, Morocco and Saudi Arabia. They use the "between estimator" panel data regression to test whether price-earnings ratio, book-to-market ratio, market capitalization, and beta can predict stock market return variations. Their results show that beta has a highly significant explanatory power in predicting stock market returns; while the other fundamentals fail the test.

In the Jordanian context, Al Refai (2009) tests the unconditional and conditional CAPM in the Amman Stock Exchange using portfolios formed based on industries. He finds a significant risk-return relationship in up markets but does not find any significant relationship in down markets for some portfolios. Khasawneh (2010) tests the Fama and French three factor model in Amman Stock Exchange (ASE) using monthly data over the period 2001-2010. He finds statistically significant value and size effects. Moreover, he shows evidence that the Fama\& French three factor model provides better explanation to the variations in stock returns than the CAPM in ASE. Al-Mwalla, and Karasneh (2011) reach to the same conclusion for the same stock exchange using monthly data from Jun 1999 to June 2010.To the best of author's knowledge, this is the first study worldwide that tests the recently developed Fama and French (2015) five factor model.

\section{Data and Methodology}

The data set of the study consists of the daily observations of all the companies listed in Amman Stock Exchange over the period (2011-2015) inclusive. However, a filtering process is performed in order to avoid the thinly traded stocks. In order for the company to be included in our sample the stock should meet the following criteria:

- It should be listed over the study period.

- It should be traded at least once every 10 days.

- Stocks that had mergers or split are excluded.

The filtering process results in 84 companies with 104,328 observations. The methodology of the study is based on estimating three asset pricing models as follows: 


\section{The Capital Asset Pricing Model (CAPM)}

Where:

$$
R_{i t}-R f_{t}=\alpha_{0}+\alpha_{1}\left(R m_{t}-R f\right)+e_{i t}
$$

- $\quad R_{i t}$ is the daily return on stock $i$ on day $t$.

- $R f_{t}$ is the daily risk free rate on day $t$..

- $R m_{t}$ is the daily rate of return on the free float market index on day $t$..

\section{The Fama and French Three Factor Model}

Where:

$$
R_{i t}-R f_{t}=\beta_{0}+\beta_{1}\left(R m_{t}-R f\right)+\beta_{2} S M B_{t}+\beta_{3} H M L_{t}+\varepsilon_{i t}
$$

- $S M B_{t}$ : is the (small minus big) common risk factor on day $t$ that had been introduced by Fama and French (1993). It represents the difference in return between the portfolio of smallest size stocks and the portfolio of biggest size stocks in the market. Portfolios are formed in June of year $t$ based on the market capitalization (a proxy for size) measured with accounting data for the fiscal year ending in $t-1)$.

- $\quad H M L_{i}$ is the (high minus low) common risk factor on day $t$ that had been introduced by Fama and French (1993). It represents the difference in return between the portfolio of highest book to market ratio stocks and the portfolio of lowest book to market ratio stocks in the market. Portfolios are formed in June of year $t$ based on the book to market ratio measured with accounting data for the fiscal year ending in $t-1$ ).

\section{The Fama and French Five Factor Model}

$$
R_{i t}-R f_{t}=\phi_{0}+\phi_{1}\left(R m_{t}-R f\right)+\phi_{2} S M B_{t}+\phi_{3} H M L_{t}+\phi_{4} R M W_{t}+\phi_{5} C M A_{t}+\gamma_{i t}
$$

Where:

- $R M W_{t}$ : is the (robust minus weak) common risk factor on day $t$ that had been introduced by Fama and French (2015). It represents the difference in return between the portfolio of highest profitability stocks and the portfolio of lowest profitability stocks in the market. Portfolios are formed in June of year $t$ based on the profitability measured with accounting data for the fiscal year ending in $t-1$ ). Profitability is calculated by the annual revenues minus cost of goods sold, interest expense, and selling, general, and administrative expenses, all divided by book equity at the end of fiscal year $t-1$.

- $\quad C M A_{t}$ : is the (conservative minus aggressive) common risk factor on day $t$ that had been introduced by Fama and French (2015). It represents the difference in return between the portfolio of most conservative stocks and the portfolio of most aggressive stocks in the market. Portfolios are formed in June of year $t$ based on the growth of total assets for the fiscal year ending in $t-1$ divided by total assets at the end of $t-1$. Conservative stocks are defined as those with the lowest growth of total assets while aggressive stocks are defined as ones with the highest growth of total assets.

All the common risk factors are calculated by dividing the sample stocks to five groups according a certain criterion and thereafter calculating the difference in returns between the two portfolios of the first and fifth quintiles. The portfolios are reconstructed on a yearly basis.

The three models are estimated using pooled, fixed effect panel and random effect panel regressions. The Lagrange multiplier and Hausman tests are insignificant indicating that the pool estimation is preferred to our data set. 


\section{Results and Analysis}

Table 1 summarizes the descriptive statistics of the study variables. The excess market returns (Rm-Rf) averages -0.0002 on a daily basis over the study period. The daily averages of the SMB, HML, RMW and CMA are $0.0001,0.0013,0.0006$ and -0.0008 , respectively. On a monthly basis these values are equivalent to $0.002,0.026,0.012$ and -0.016 , respectively assuming 20 trading days a month. When comparing these means to those of the NYSE reported by Fama and French (2015), we find big differences. Fama and French (2015) report that the monthly averages of the excess market return (Rm-Rf), SMB, HML, RMW and CMA are $0.46,0.29,0.38,0.26,0.33$, respectively.

\section{Table (1) Descriptive Statistics}

\begin{tabular}{lccccc}
\hline STATS & $(\mathbf{R m}-\mathbf{R f})$ & SMB & HML & RMW & CMA \\
\hline Mean & -0.0002 & 0.0001 & 0.0013 & 0.0006 & -0.0008 \\
\hline Median & 0.0000 & -0.0003 & 0.0006 & 0.0002 & -0.0010 \\
\hline Maximum & 0.0236 & 0.0462 & 0.0599 & 0.0792 & 0.2060 \\
\hline Minimum & -0.0295 & -0.0623 & -0.0548 & -0.0918 & -0.0658 \\
\hline Std. Dev. & 0.0064 & 0.0186 & 0.0204 & 0.0194 & 0.0236 \\
\hline
\end{tabular}

Table 2 shows the correlation matrix between the study variables. The correlation values show that each common risk factor is independent from the other. Thus, each factor reflects a different aspect of asset pricing. No muticollinearity problem exists, the largest correlation value is $-35 \%$ between RMW and CMA.

Table (2) Correlation Matrix

\begin{tabular}{lccccc}
\hline & (Rm-Rf) & SMB & HML & RMW & CMA \\
\hline (Rm-Rf) & 1.0000 & -0.0696 & 0.0732 & -0.0430 & 0.1682 \\
\hline SMB & -0.0696 & 1.0000 & -0.0101 & -0.0845 & 0.0646 \\
\hline HML & 0.0732 & -0.0101 & 1.0000 & 0.0900 & 0.0005 \\
\hline RMW & -0.0430 & -0.0845 & 0.0900 & 1.0000 & -0.3491 \\
\hline CMA & 0.1682 & 0.0646 & 0.0005 & -0.3491 & 1.0000 \\
\hline
\end{tabular}

Table 3 shows the estimation results of the CAPM. The results will be discussed based on the pooled regression analysis. As expected, the excess market return is highly significant and positive. Its coefficient equals 0.9539 . However, the CAPM does not perfectly explain the cross section of stock returns given its statistically significant intercept. The results are very similar regardless of the estimation method. These results are consistent with nearly all of the previous studies who document highly significant effect of excess market return as a common risk factor (see for example, Fama and French, 1993, 2015; Al-Rjoub, et al., 2010; Al-Mwalla, and Karasneh, 2011). The pooled adjusted R2 is $6.41 \%$.

Table (3) The Capital Asset Pricing Model

\begin{tabular}{lccc}
\hline Independent & Pooled & Fixed & Random \\
\hline Intercept & 0.0002 & 0.0002 & 0.0002 \\
\hline T-Statistic & 2.5738 & 2.5748 & 2.4905 \\
\hline Prob. & 0.0101 & 0.0100 & 0.0128 \\
\hline (Rm-Rf) & 0.9539 & 0.9542 & 0.9539 \\
\hline T-Statistic & 77.0985 & 77.1196 & 77.1054 \\
\hline Prob. & 0.0000 & 0.0000 & 0.0000 \\
\hline LM & 95.1390 & & \\
\hline & 0.1708 & 2.3917 \\
\hline Hausman & & & 0.1220 \\
\hline & & & 0.0641 \\
\hline Adjusted R2 & 0.0641 &
\end{tabular}


Table 4 reports the estimation results of the Fama and French three factor model. The results are similar regardless of the estimation method. Table 4 shows that both the excess market return ( $\mathrm{Rm}-\mathrm{Rf})$ and the SMB are statistically significant and positive with coefficients of 0.9443 and 0.0734 , respectively. These results are consistent with (Fama and French, 1993, 2015; Khasawneh, 2010; Al-Mwalla, and Karasneh, 2011). However, the HML shows insignificant effect as a common risk factor on the cross section of stock returns in ASE over the study period (2009-2013). These results are contrasting with the USA results reported by (Fama and French, 1993). Moreover, these results are distinct from (Khasawneh, 2010; Al-Mwalla, and Karasneh, 2011) in the Jordanian context. However, they are consistent with Fama and French (2015) who recently reported that the five-factor model never improves the description of average returns from the four-factor model that includes (Rm-Rf), SMB, RMW, CMA and drops HML. Overall, Fama and French three factor model does not entirely explain the cross section of stock returns in ASE given its statistically significant intercept.

Table (4) Fama and French Three Factor Model

\begin{tabular}{lccc}
\hline Independent & Pooled & Fixed & Random \\
\hline intercept & 0.0002 & 0.0002 & 0.0002 \\
\hline t-Statistic & 2.1207 & 2.1228 & 2.0230 \\
\hline Prob. & 0.0339 & 0.0338 & 0.0431 \\
\hline (Rm-Rf) & 0.9443 & 0.9445 & 0.9443 \\
\hline t-Statistic & 71.0793 & 71.0991 & 0.0000 \\
\hline Prob. & 0.0000 & 0.0000 & 0.0734 \\
\hline SMB & 0.0734 & 0.0735 & 15.6397 \\
\hline t-Statistic & 15.6352 & 15.6563 & 0.0000 \\
\hline Prob. & 0.0000 & 0.0000 & 0.0066 \\
\hline HML & 0.0066 & 0.0065 & 1.5450 \\
\hline -Statistic & 1.5468 & 1.5290 & 0.1224 \\
\hline Prob. & 0.1219 & 0.1263 & \\
\hline LM & 99.8472 & & 4.2990 \\
\hline Hausman & 0.1004 & & 0.2309 \\
\hline Adjusted R2 & & & 0.0762 \\
\hline
\end{tabular}

Table 5 reports the estimation results of Fama and French five factor model. The results indicate that all the five common risk factors included in the model are statistically significant. All of them show positive effects except the RMW which displays a negative effect on the cross section of stock returns in ASE. The importance of the common risk factors in explaining the cross section of stock returns in ASE over the study period is ranged as (Rm-Rf), SMB, RMW, CMA and HML (from the most to the least important). The model has a statistically significant intercept indicating its inability to perfectly explain the cross section of returns in ASE. However, it shows a slight improvement in the adjusted R2 to around 10\%. The results are consistent with Fama and French (2015) who find statistically significant effects of the five common risk factors on portfolio returns in USA. However, Fama and French (2015) find that the five factor model explains the returns of all constructed portfolios except the low average returns on small stocks that invest a lot despite low profitability.

Table (5) Fama and French Five Factor Model.

\begin{tabular}{lccc}
\hline Independent & Pooled & Fixed & Random \\
\hline intercept & 0.0002 & 0.0002 & 0.0002 \\
\hline t-Statistic & 2.2698 & 2.2715 & 2.2503 \\
\hline Prob. & 0.0232 & 0.0231 & 0.0244 \\
\hline (Rm-Rf) & 0.9266 & 0.9269 & 0.9266 \\
\hline
\end{tabular}




\begin{tabular}{|c|c|c|c|}
\hline Independent & Pooled & Fixed & Random \\
\hline t-Statistic & 64.6303 & 64.6462 & 64.6325 \\
\hline Prob. & 0.0000 & 0.0000 & 0.0000 \\
\hline SMB & 0.0687 & 0.0688 & 0.0687 \\
\hline t-Statistic & 13.7383 & 13.7617 & 13.7393 \\
\hline Prob. & 0.0000 & 0.0000 & 0.0000 \\
\hline $\mathrm{HML}$ & 0.0108 & 0.0107 & 0.0108 \\
\hline t-Statistic & 2.4183 & 2.3976 & 2.4180 \\
\hline Prob. & 0.0156 & 0.0165 & 0.0156 \\
\hline RMW & -0.0518 & -0.0518 & -0.0518 \\
\hline t-Statistic & -9.0318 & -9.0292 & -9.0321 \\
\hline Prob. & 0.0000 & 0.0000 & 0.0000 \\
\hline CMA & 0.0131 & 0.0131 & 0.0131 \\
\hline $\mathrm{t}$-Statistic & 2.7019 & 2.6990 & 2.7018 \\
\hline Prob. & 0.0069 & 0.0070 & 0.0069 \\
\hline \multirow[t]{2}{*}{ LM } & 86.7063 & & \\
\hline & 0.3688 & & \\
\hline \multirow[t]{2}{*}{ Hausman } & & & 6.3329 \\
\hline & & & 0.2752 \\
\hline Adjusted R2 & 0.0980 & 0.0980 & 0.0980 \\
\hline
\end{tabular}

\section{Conclusion}

This study investigates the performance of the five factor model of Fama and French (2015) in Amman Stock Exchange over the period (2011-2015). The results indicate that all the common risk factors examined, excess market return (Rm-Rf), small minus big (SMB), high minus low (HML), robust minus weak (RMW) and conservative minus aggressive (CMA) have statistically significant effects on the cross section of daily returns in ASE. However, none of the CAPM, Fama and French three factor model, Fama and French five factor model can fully explain the cross section of stock returns in this market. It seems that its unique characteristics as an emerging market makes it difficult to find the best model that can perfectly fit that data in ASE. While the asset pricing models assume perfect markets, emerging markets are not. They are characterized by information asymmetry, inefficiencies, ownership concentration, high volatility, thin trading, higher transaction costs, smaller number of investors, smaller market capitalizations and higher sample average returns than developed markets. Consequently, the task of finding how stocks are priced becomes harder than doing it in the developed stock exchanges. 


\section{References}

- Acharya, V. V. and Pedersen, L. H. (2005)."Asset Pricing with Liquidity Risk", Journal of Financial Economics, 77 (2) :375-410.

- Ajili, S. (2003). The Capital Asset Pricing Model and The Three Factor Model of Fama and French Revisited in The Case of France. Working Paper.

- Al-Mwalla, M. and Karasneh, M. (2011). “Fama and French three factor model: Evidence from emerging market", European Journal of Economics, Finance and Administrative Sciences, 41:132-140.

- Al-Rjoub, Samer, A. M.; Abdullah, Al. Y. and Izz, E. N. A. (2010). “Beta Wins Again: Case of four Emerging Markets", Journal of Economic Cooperation and Development, 31:1-16.

- Al Refai, H. (2009). Empirical Test of the Relationship between Risk and Returns in Jordan Capital Market. Working Paper. Retrieved from: SSRN: http://ssrn.com/abstract=1443367.

- Ang, A. and Chen, J. (2007). "CAPM Over the Long Run: 1926-2001", Journal of Empirical Finance, 14(1):1-40.

- Banz, R. W. (1981). "The Relationship between Return and Market Value of Common Stocks", Journal of Financial Economics, 9 (1): 3-18.

- Basu, S. (1977). "Investment Performance of Common Stocks in Relation to Their Price-Earnings Ratios: A Test of the Efficient Market Hypothesis", Journal of Finance, 32 (3): 663-682.

- Basu, S. (1983). “The Relationship between Earnings Yield, Market Value and the Return for NYSE Common Stocks", Journal of Financial Economics, 12: 126-156.

- Bello, Z. (2008). "A Statistical Comparison of the CAPM to the Fama-French Three Factor Model and The Carhart Model", Global Journal of Finance and Banking Issues, 2 (2):1-14.

- Black, F. (1972).“Capital Market Equilibrium with Restricted Borrowing”, Journal of Business, 45 (3): 444-54.

- Black, F.; Jensen, M. C. and Scholes, M. (1972). "The Capital Asset Pricing Model: Some Empirical Tests", (M. Jensen, Ed.) Studies in the Theory of Capital Markets, 81(3):79-121.

- Breeden, D. T. (1979). "An Intertemporal Asset Pricing Model with Stochastic Consumption and Investment Opportunities", Journal of Financial Economics, 7 (3): 265-96.

- Carhart, M. (1997). “On the Persistence in Mutual Fund Performance”, Journal of Finance, 52 (1): 57 -82 .

- Chan, L. K. C.; Hamao, Y. and Lakonishok, J. (1991). “Fundamentals and Stock Returns in Japan”, Journal of Finance, 46 (5): 1739-1764.

- Chui, A. C. W. and Wei, K.C.J. (1998). "Book-to-market, firm size, and the turn-of-the-year effect: evidence from Pacific Basin emerging markets", Pacific-Basin Finance Journal, 6 (3-4): 275-293.

- Cochrane, J. H. (1991)."Production-based Asset Pricing and the Link between Stock Returns and Economic Fluctuations", The Journal of Finance, 46 (1): 209-37.

- Connor, G. and Sehgal, S. (2001). Tests of the Fama and French model in India, Working Paper, London School of Economics, United Kingdom.

- Daniel, K. and Titman, S. (1996). "Evidence on the Characteristics of Cross Sectional Variation in Stock Returns". Working Paper. http://www.nber.org/papers/w5604.pdf?new_window=1.

- Davis, J. L.; Fama, E. F. and French, K.F. (2000). “Characteristics, Covariance and Average Returns: 1929 to 1997", Journal of Finance, 55 (1): 389-406.

- Faff, R. (2001). "An Examination of the Fama and French Three-factor Model Using Commercially Available Factors", Australian Journal of Management, 26 (1): 1-17.

- $\quad$ Fama, E. F. and French, K. R. (1992)."The Cross-section of Expected Returns”, Journal of Finance, 47 (2): 427-465. 
- Fama, E. F. and French, K. R. (1993). “Common Risk Factors in the Returns on Stocks and Bonds" Journal of Financial Economics, 33(1): 3-56.

- Fama, E. F. and French, K. R. (2015). "A Five-factor Asset Pricing Model", Journal of Financial Economics, 116 (1): 1-22.

- Fama, E. F. and MacBeth, J. D. (1973). "Risk, Return and Equilibrium: Empirical Tests", The Journal of Political Economy, 81: 607-636.

- $\quad$ Fama, F. and French, K. R. (1996)."Multifactor Explanations of Asset Pricing Anomalies", Journal of Finance, 51(1): 55-84.

- Fletcher, J. (2000). “On the Conditional Relationship between Beta and Return in International Stock Returns", International Review of Financial Analysis, 9 (3): 235-245.

- Fraser, P.; Hamelink, F.; Hoesli, M. and McGregor, B. (2004). “Time-varying Betas and Cross-sectional Return-risk Relation: Evidence from the UK", European Journal of Finance, 10 (4): 255-76.

- Gokgoz, F. (2007). "Testing the Asset Pricing Models in Turkish Stock Markets: CAPM vs Three Factor Model", International Journal of Economic Perspectives, 1 (2): 103-117.

- Groenewold, N. and Fraser, P. (1997). "Share Prices and Macroeconomic Factors", Journal of Business Finance and Accounting, 24: 1367-1383.

- Jagannathan, R. and Wang, Z. (1996). "The Conditional CAPM and the Cross-section of Expected Returns", Journal of Finance, 51 (1): 3-53.

- Khasawneh, M. (2010). "An Empirical Test of Fama and French Three Factor Model in Amman Stock Exchange". Master Thesis. Yarmouk University. Jordan.

- Lintner, J. (1965). “The Valuation of Risk Assets and the Selection of Risky Investments in Stock Portfolios and Capital Budgets", Review of Economics and Statistics, 47 (1): 13-37.

- L'Her J.; Masmoudi T. and Suret J. (2004). “Evidence to Support the Four-factor Pricing Model From the Canadian Stock Market", Journal of Int. Fin. Markets, Inst. and Money, 14: 313-328.

- Markowitz, H. M. (1952).“Portfolio Selection”, Journal of Finance, 7 (1): 77-91.

- Merton, R. C. (1973). “An Intertemporal Capital Assets Pricing Model”, Econometrica, 41 (5): 867-87.

- Petkova, R. and Zhang, L. (2005). "Is Value RiskierThan Growth?", Journal of Financial Economics, 78 (1): 187-202.

- Pettengill, G. N.; Sundaram, S. and Mathur, I. (1995)."The Conditional Relation between Beta and Returns", The Journal of Financial and Quantitative Analysis, 30 (1): 101-116.

- Rosenberg, B.; Reid, K. and Lanstein, R. (1985). "Persuasive Evidence of Market Inefficiency”, Journal of Portfolio Management, 11 (3): 9-17.

- Ross, S. (1976). "Arbitrage Theory of Capital Asset Pricing", Journal of Economic Theory, 13 (3): 341360.

- Sharpe, W. F. (1964).“Capital Asset Prices: A Theory of Market Equilibrium under Conditions of Risk”, Journal of Finance, 19 (4): 425-442.

- Tai, Chu-Sheng. (2003). "Are Fama \& French and Momentum Factors Really Priced?", Journal of Multi FinancialManagement,13: 359-384.

- Theriou, N. G. Aggelidis, V. P. and Sevic, Z. (2010). "Testing the Relationship between Beta and Returns in the Athens Stock Exchange", Managerial Finance, 36 (12): 1043-1056.

- Tobin, J. (1958). "Liquidity Preference as Behavior toward Risk", Review of Economic Studies, 25: 6885. 